\title{
MENINGKATKAN KINERJA MELALUI KOMITMEN DAN BUDAYA ORGANISASI
}

\author{
Zufrie \\ Email : zufrieanhal@ rocketmail.com \\ Dosen Tetap STIE Labuhanbatu
}

\begin{abstract}
ABSTRAK:
Dalam dunia usaha dibutuhkan personal yang mempunyai kinerja yang baik. Dengan kinerja yang baik maka tujuan persahaan akan dapat dicapai secara optimal.Untuk meningkatkan kinerja dibutuhkan sebuah komitmen dari karyawan. Organisasi adalah alat untuk mencapai tujuan yang harus bisa untuk memberikan kejelasan kepada salah seorang, status dalam organisasi baik dari segi ikatan, posisi dan peran. Salah satu upaya untuk meningkatkan kinerja adalah perhatian terhadap komitmen, dan budaya orgnisasi untuk karyawan sebuah perusahaan. Kesediaan untuk bekerja keras dan keinginan untuk mempertahankan keanggotaan, meningkatkan kemampuan organisasi memerlukan budaya organisasi dengan hubungan interpersonal. Dalam situasi ini sebuah organisasi membutuhkan budaya organisasi, norma dan praktik yang berlaku setiap hari. Komitmen dan budaya organisasi merupakan dua hal yang di perlukan terhadap efektivitas dan efisiensi kerja.
\end{abstract}

Kata kunci: kinerja, komitmen, budaya organisasi

\section{PENDAHULUAN}

Untuk meningkatkan kinerja dalam suatu organisasi, yang menjadi prioritas utama adalah mengoptimalkan sumber daya manusia. Sehingga dapat dikatakan bahwa sumber daya manusia (SDM) menjadi faktor kunci dalam rangka memperoleh kinerja yang baik.

Agar organisasi berfungsi secara efektif dan sesuai dengan sasaran organisasi, maka organisasi harus memiliki kinerja karyawan yang baik yaitu dengan melaksanakan tugastugasnya dengan cara yang handal (Simamora, 1997:339)

Kinerja seseorang dalam pekerjaannya paling dominan ditentukan dari komitmen, profesional dan tingkat kompetensi terhadap bidang yang ditekuninya. Suatu komitmen organisasional menunjukkan suatu daya dari sesorang dalam mengidentifikasikan keterlibatan dalam suatu organisasi. Oleh karena itu komitmen organisasional akan menimbulkan rasa tanggung jawab bagi pekerja terhadap organisasi.

Terjadinya perubahan-perubahan dalam budaya organisasi juga mempunyai dampak pada terjadinya perubahan dalam tugas dan kewajiban pegawai. Para pegawai diharapkan menjadi lebih kreatif mencari cara baru untuk memperbaiki efektivitas dan efisiensi kerja di organisasi. Ketika organisasi mengurangi jumlah pegawai, organisasi itu akan lebih tergantung pada pegawai yang tetap tinggal untuk melakukan hal-hal melebihi apa yang ditugaskan kepada mereka. 


\section{KINERJA Pengertin Kinerja}

Pengertian kinerja menurut para ahli dapat diuraikan sebagai berikut :

1. Kinerja atau prestasi kerja adalah hasil kerja secara kualitas dan kuantitas yang dicapai oleh seorang pegawai dalam melaksanakan tugasnya sesuai dengan tanggung jawab yang diberikan kepadanya (Anwar Prabu Mangkunegara, 2006:67)

2. Kinerja karyawan adalah hasil dari proses pekerjaan tertentu secara berencana pada waktu dan tempat dari karyawan serta organisasi bersangkutan (Mangkuprawira dan Hubeis, 2007:153).

3. Kinerja didefinisikan sebagai seperangkat hasil yang dicapai dan merujuk pada tindakan pencapaian serta pelaksanaan sesuatu pekerjaan yang diminta (Stolovitch and Keeps, 1992)

4. Kinerja adalah salah satu kumpulan total dari kerja yang ada pada diri pekerja (Griffin, 1987)

5. Kinerja merupakan suatu fungsi dari motivasi dan kemampuan. Untuk menyelesaikan tugas atau pekerjaan seseorang harus memiliki derajat kesediaan dan tingkat kemampuan tertentu. Kesediaan dan ketrampilan seseorang tidaklah cukup efektif untuk mengerjakan sesuatu tanpa pemahaman yang jelas tentang apa yang akan dikerjakan dan bagaimana mengerjakannya (Hersey and Blanchard, 1993)

6. Pengertian kinerja merujuk pada tingkat keberhasilan melaksanakan tugas serta kemampuan mencapai tujuan yang telah ditetapkan. Kinerja dinyatakan baik dan sukses jika tujuan yang diinginkan dapat tercapai dengan baik (Donelly, Gibson and Ivancevich, 1994)

7. Kinerja sebagai kualitas dan kuantitas pencapaian tugas-tugas, baik yang dilakukan oleh individu, kelompok maupun perusahaan (Schermerhorn, Hunt and Osborn, 1991)

8. Kinerja adalah hasil kerja yang dicapai seseorang dalam melaksanakan tugastugasnya atas kecakapan, usaha dan kesempatan. Berdasarkan paparan diatas kinerja adalah suatu hasil yang dicapai seseorang dalam melaksanakan tugastugas yang didasarkan atas kecakapan, pengalaman dan kesungguhan serta waktu menurut standar dan kriteria yang telah ditetapkan sebelumnya (Hasibuan, 2002:160)

Dari berbagai defenisi kinerja yang diuraikan para ahli tersebut dapat disimpulkan bahwa kinerja adalah kualitas kerja yang dilakukan seseorang pada suatu organisasi untuk mencapai tujuan yang dicita-citakan organisasi tersebut.

\section{Faktor yang Mempengaruhi Kinerja}

Faktor-faktor yang mempengaruhi kinerja adalah sebagai berikut :

1. Fasilitas, Ada tidaknya sarana dan prasarana yang mendukung seseorang karyawan bekerja di kantor. Dengan fasilitas yang tersedia, karyawan akan melaksanakan tugasnya dengan maksimal. Berbeda halnya dengan perusahaan baru (startup) dimana fasilitas masih minim. Untuk mengatasi hal ini, berikan pengarahan di awal kepada para karyawan, sehingga karyawan memiliki komitmen sejak dari awal untuk bekerja dengan maksimal meskipun dengan fasilitas yang minim. Namun, berbeda kasus jika di perusahaan yang sudah mapan ternyata minim fasilitas, maka kinerja karyawan pasti akan terhambat karena fasilitas. 
2. Kondisi dan suasana lingkungan kerja. Lingkungan kantor juga sangat berpengaruh pada kinerja karyawan. Bagaimana suasana ruangan kantor, misalnya apa warna cat dinding di kantor, seberapa luas ruang kerja di kantor, kebiasaankebiasaan sederhana karyawan di kantor, bagaimana cara berkomunikasi karyawan kantor, dan banyak lagi yang lain. Untuk menciptakan lingkungan kerja yang kondusif serta nyaman perlu untuk menata dan membuat aturan-aturan kecil yang disepakati bersama.

3. Skala prioritas kerja yang jelas. Delegasikan alur kerja yang jelas, memiliki SOP yang jelas, sehingga karyawan akan bekerja mengikuti SOP (standar oprasional prosedur) yang sudah ada. Dengan prioritas kerja maka akan terjadi efisiensi dan efektivitas dalam pekerjaan. Berikan prioritas kerja yang jelas terhadap karyawan, jangan bebankan terlalu banyak tugas kepada karyawan, sehingga mereka akan merasa kebingungan mana pekerjaan yang harus diprioritaskan terlebih dahulu mana yang tidak.

4. Dukungan (support) dari atasan. Sebagai pemimpin yang baik, harus mendengarkan pendapat dan ide karyawannya. Berikan support kepada mereka dalam menyampaikan gagasan dan ide-ide baru saat rapat. Libatkan mereka dalam menyelesaikan sebuah permasalahan yang ada. Dengarkan ide ide mereka, karena pada akhirnya ide ini yang kan membawa sebuah kemajuan bagi perusahaan. Ajak mereka ikut berperan aktif dalam melakukan trobosan-trobosan penting dalam perusahan.

5. Apresiasi dan bonus. Berikan apresiasi kepada karyawan setiap kali mereka selesai mengerjakan tugas. Setiap karyawan akan bekerja dengan segenap kemampuan jika pekerjaan yang mereka kerjakan dihargai oleh perusahaan. Bukan hanya di hargai dengan bonus uang saja, namun juga dengan apresiasi pujian dari atasan. Berikan pujian pada momen tertentu dan disaksikan oleh karyawan lain, karena prosesi ini akan meningkatkan motivasi karyawan untuk bekerja dengan sebaik mungkin. Mereka berharap akan mendapatkan apresiasi dan bonus seperti teman mereka yang sudah mendapatkannya.

\section{KOMITMEN Pengertian Komitmen}

Komitmen berasal dari kata commit, artinya melakukan, mempercayakan dan menyerahkan. Commitment artinya melakukan janji-janji dan tanggung jawab. Komitmen merupakan suatu sikap kerja (job attitude) atau keyakinan yang mencerminkan kekuatan relatif dan keberpihakan dan keterlibatan individu pada suatu organisasi. Mathis dan Jakson, (2006:113) memberikan defenisi, "Organization Commitment is the degree to which employees belive in and accept organization goals and desire to remain with the organization". Komitmen organisasional adalah derajat yang mana karyawan percaya dan menerima tujuan-tujuan organisasi dan akan tetap tinggal atau tidak akan meninggalkan organisasi.

Sebagai suatu sikap, Luthans seperti dikutip Sutrisno,(2010:292) menyatakan komitmen organisasi merupakan: (1) keinginan yang kuat untuk menjadi anggota dalam suatu kelompok; (2) kemauan usaha yang tinggi untuk organisasi; (3) suatu keyakinan tertentu dan penerimaan terhadap nilai-nilai dan tujuan-tujuan organisasi. 


\section{Faktor yang Mempengaruhi Komitmen}

Schatz dan Schatz 1995 seperti di kutip Hasan, (2007:21) mengatakan bahwa komitmen merupakan hal yang paling mendasar bagi setiap orang dalam pekerjaannya. Tanpa ada suatu komitmen tugas-tugas yang di berikan kepadannya sukar untuk terlaksana dengan baik. Komitmen yang tinggi terhadap tugas dapat menimbulkan motivasi seseorang untuk melakukan sesuatu dengan penuh keiklasan. Sahertian (2000:44) mengatakan bahwa komitmen terhadap tugas merupakan kecenderungan dalam diri seseorang untuk merasa terlibat aktif dengan penuh tanggung jawab. Dapat diartikan seseorang yang berkomitmen tinggi terhadap tugas dia akan lebih giat dan gigih dalam menyelesaikan tugas dan tanggung jawab yang di berikan kepadanya.

Komitmen seseorang dalam melaksanakan tugas yang di berikan kepadanya tidak sama setiap orang. Minner (1992:134) mengemukakan empat faktor yang mempengaruhi komitmen karyawan pada organisasi, yaitu:

(1) Faktor personal, misalnya usia, jenis kelamin, tingkat pendidikan, pengalaman kerja, kepribadian, dll; (2) karakteristik pekerjaan, misalnya lingkup jabatan, tantangan dalam pekerjaan, konflik peran dalam pekerjaan, tingkat kesulitan dalam pekerjaan, dll; (3) karakteristik struktur. Misalnya besar/kecilnya organisasi, bentuk organisasi seperti sentralisasi atau desentralisasi, kehadiran serikat pekerja dan tingkat pengendalian yang di lakukan organisasi terhadap karyawan; dan (4) pengalaman kerja.

Pengalaman kerja karyawan sangat berpengaruh terhadap tingkat komitmen karyawan pada organisasi. Karyawan yang baru beberapa tahun bekerja dan karyawan yang sudah puluhan tahun bekerja dalam organisasi tentu memiliki tingkat komitmen yang berlainan. Lebih lanjut dikatakannya, secara konseptual terdapat tiga faktor yang mempengaruhi komitmen yaitu: (1) suatu keyakinan yang kuat sertan menerima tujuantujuan serta nilai-nilai organisasi; (2) kemauan untuk melaksanakan upaya untuk kepentingan organisasi; dan (3) adanya suatu keinginan yang kuat untuk memelihara keanggotaan dalam organisasi.

Seseorang yang mempunyai tanggung jawab yang tinggi terhadap pekerjaan nya dapat diindikasikan mempunyai komitmen organisasional yang tinggi. Identifikasi dan identitas setiap individu pada suatu organisasi akan menyebabkan orang tersebut memiliki komitmen yang berbeda pula terhadap organisasi. Komitmen seseorang dalam melaksanakan kerjanya mempunyai ciri yang berbeda-beda, tergantung kepada apa yang diinginkannya. Sehingga komitmennya akan nampak dari tingkah laku atau perilakunya terhadap organisasinya.

\section{BUDAYA ORGANISASI Pengertian Budaya Organisasi}

Budaya menurut kamus bahasa indonesia adalah kebudayaan ,akal budi, pikiran manusia yang mempunyai peradaban. Mulyana dan Rakmat (2003:18) secara formal mendefinisikan budaya sebagai tatanan pengetahuan, pengalaman, kepercayaan, nilai, sikap, makna, hierarki, agama, waktu, peranan, hubungan, makna, konsep alam semesta, obyek-obyek materi dan milik yang di peroleh sekelompok besar orang dari generasi 
kegenerasi melalui usaha individu dan kelompok. Budaya menggambarkan cara seseorang melakukan segala sesuatu.

Dengan demikian budaya merupakan suatu konsep yang membangkitkan minat dan berkenaan dengan cara manusia hidup, belajar, berfikir, merasa, mempercayai dan mengusahakan apa yang patut dilakukan. Budaya dapat eksis karena ada pelakunya yaitu pelaku budaya. Menurut Yulk (2007:335) fungsi utama dari budaya adalah membantu memahami lingkungan dan menentukan bagaimana meresponnya, yang karenanya mengurangi kecemasan, ketidakpastian, dan kebingungan. Penjelasan ini menggambarkan, bahwa organisasi yang mempunyai budaya yang baik akan menjadikan organisasi itu lebih yakin dan lebih pasti untuk mencapai sasaran atau tujuan sasaran atau tujuan yang ditetapkan.

Organisasi adalah perkumpulan, susunan atau aturan dari berbagai bagian. Organisasi mempunyai budaya sendiri yang terbentuk dari karakteristik organisasi sebagai obyek dan subyeknya. Setiap organisasi mempunyai budaya organisasi yang memengaruhi semua aspek organisasi dan perilaku anggotanya secara individual dan kelompok. Organisasi memiliki visi,misi dan tujuan strategis yang diharapkan akan dicapai melalui interaksi dan kerja sama seluruh anggota organisasi. Sebagai organisasi individu dituntut untuk menyesuaikan diri dengan apa yang telah ditetapkan organisasi. Setiap orang dalam oraganisasi memiliki tugas, tanggung jawab, dan wewenang sesuai dengan kedudukan dan perannya dalam organisasi. Selain itu, penghargaan yang di berikan organisasi kepada anggotanya juga turut mempengaruhi perilaku individu dalam organisasi, kesemuanya ini disebut sebagai karakteristik organisasi.

Penggunaan istilah budaya organisasi dengan mengacu pada budaya yang berlaku pada organisas, yaitu kerja sama antara beberapa orang yang membentuk kelompok atau satuan kerjasama tersendiri. Robbins seperti dikutip sopiah, (2008:128) memberi definisi budaya organisasi merupakan nilai-nilai dominan yang didukung oleh organisasi, falsafah yang menuntut kebijakan organisasi terhadap pegawai dan pelanggan, cara pekerjaan dilakukan, dan asumsi atau kepercayaan yang terdapat diantara anggota organisasi. Selanjutnya Brown seperti dikutip Sagal (2008:12) menyebutkan budaya organisasi merupakan kofigurasi unik dari norma, nilai, keyakinan, cara bersikap, dan sebagai nya yang menjadi karakter atau sikap seseorang baik secara individu maupun kelompok, sehingga berbagai persoalan dapat terselesaikan.

Sutrisno (2010:2) mendefinisikan budaya organisasi sebagai perangkat system nilai-nilai (values), keyakinan-keyakinan (beliefs), asumsi-asumsi (assumptions), atau normanorma yang telah lama berlaku, disepakati dan dikuti oleh para anggota suatu organisasi sebagai pedoman perilaku dan pemecahan masalah-masalah organisasi. Dalam budaya organisasi terjadi sosisalisasi nilai-nilai dan menginternalisasi dalam diri para anggota, menjiwai orang per orang di dalam organisasi. Hal ini sesuai dengan yang dikemukakan Kilmann seperti dikutip sutrisno,(2010:2) bahwa budaya organisasi merupakan jiwa organisasi dan jiwa para anggota organisasi.

Dari berbagai pendapat diatas dapat disimpulkan bahwa budaya organisasi adalah nilainilai,norma,asumsi dan filsafat organisasi yang di perkenalkan dan diajarkan serta diterapkan dalam kegiatan organisasi yang memengaruhi pola fikir, sikap dan perilaku anggota organisasi. Budaya organisasi yang terbentuk, dikembangkan, diperkuat atau bahkan di ubah,memerlukan praktik yang dapat membantu menyatukan nilai budaya anggota dengan nilai budaya organisasi. 


\section{Fungsi Budaya Organisasi}

Menurut Luthans (1998:136) ada beberapa langkah sosialisasi yang dapat membantu dan mempertahankan budaya organisasi, yakni: melalui seleksi calon karyawan, penempatan,pendalaman bidang pekerjaan, penilaian kinerja'dan pemberian penghargaan, penanaman kesetiaan pada nilai-nilai luhur, perluasan cerita dan berita, pengakuan kinerja dan promosi.

Budaya organisasi dapat digunakan sebagai salah satu alat manajemen untuk mencapai efisiensi, efektivitas, produktivitas, etos kerja. Budaya yang kuat dan positif sangat berpengaruh terhadap perilaku dan efektifitas kinerja perusahaan sebagaimana dinyatakan oleh Robbins seperti dikutip Sutrisno (2010:3). Hal ini didukung oleh Miller seperti dikutip Sutrisno (2010:4) yang menyatakan bahwa terdapat nilai-nilai primer perusahaan apabila dikelola dengan baik dapat menjadi budaya organisasi yang positif, dan akan mengakibatkan efektifitas, inovasi, loyalitas, dan produktivitas. Nilai-nilai budaya itu tampak, tetapi merupakan kekuatan yang mendorong perilaku untuk menghasilkan efektifitas kinerja.

Menurut Robbins (2006:725) budaya menjalankan sejumlah fungsi di dalam organisasi. Pertama, budaya mempunyai peran menetapkan tapal batas; artinya budaya menciptakan pembedaan yang jelas antara satu organisasi dan yang lain. Kedua, budaya memberikan ras identitas ke anggota-anggota organisasi. Ketiga, budaya mempermudah timbulnya komitmen pada sesuatu yang lebih puas daripada kepentingan pribadi seseorang. Keempat, budaya itu meningkatkan kemantapan sosial. Dalam hubungannya dengan segi sosial, budaya organisasi berfungsi sebagai perekat sosial yang membantu mempersatukan organisasi itu dengan memberikan standar-standar yang tepat untuk apa, dan apa yang harus dikatakan dan di lakukan oleh para karyawan.

Banyak dimensi-dimensi yang membedakan budaya. Gibson (1996:312) menybutkan ada tujuh dimensi budaya, yakni : hubungan manusia dengan alam, individualisme versus kolektivisme, orientasi waktu, orientasi aktivitas, informalitas, bahasa dan kepercayaan. Sedangkan dimensi-dimensi yang di gunakan untuk membedakan budaya organisasi menurut Robbins (1996:423) ada tujuh karakteristik primer yang secara bersama-sama menangkap hakikat budaya organisasi, yaitu: inovasi dan pengambilan resiko, perhatian ke hal yang rinci, orientasi hasil, orientasi orang ,orientsi tim, keagresifan, dan kemantapan.

Selanjutnya Luthans (1998:441) menyebutkan sejumlah karakteristik yang penting dari budaya organisasi, yang meliputi: aturan-aturan perilaku, norma, nilai-nilai pedoman, filosofi, peraturan-peraturan, dan iklim organisasi.

Mengenai hubungan antara dimensi-dimensi budaya organisasi Edgar H.Schein seperti dikutip Wirawan (2008:12) melukiskan budaya organisasi dalam tiga level, yaitu: (1) Artefak, pada level ini merupakan dimensi yang paling terlihat dari budaya organisasi, merupakan lingkungan fisik dan sosial organisasi. Orang yang memasuki suatu organisasi dapat melihat dengan jelas bangunan, output (barang dan jasa), teknologi, bahasa tulis dan lisan, produk seni, dan perilaku anggota organisasi. (2) Nilai-nilai, semua pembelajaran organisasi merefleksikan nilai-nilai anggota organisasi, perasaan mereka mengenai apa yang seharus nya berbeda dengan apa yang adanya. Jika anggota organisasi menghadapi persoalan atau tugas baru, solusinya adalah nilai-nilai. (3) asumsi dasar, asumsi dasar merupakan solusi yang paling dipercaya sama dengan teori ilmu pengetahuanyang sedang diterapkan untuk suatu problem yang di hadapi organisasi. 
Budaya organisasi yang paling mungkin membentuk standar etis tinggi adalah budaya yang tinggi dalam mentolelir resiko rendah sampai sedang dalam keagresifan, dan berfokus pada sarana dan juga hasil. Para pimpinan dalam budaya semacam itu didukung untuk mengambil resiko dan melakukan inovasi, ikut melibatkan diri dalam persaingan yang tak terkendali, dan memberikan perhatian pada bagaimana caranya mencapai sasaran dan sasaran apa yang mau dicapai. Hal ini sejalan dengan apa yang dikemukakan Sagala (2008:120) bahwa sumber budaya organisasi adalah para pemimpin dan pendirinya yang dipertahankan melalu proses seleksi dan sosialisasi organisasi serta tindakan manajemen puncak (strategic apex). Sebenarnya budaya dapat diubah, tetapi diperlukan beberapa kondisi untuk melakukan perubahan tersebut. Pada kondisi yang menguntungkan sekalipun para pimpinan tidak dapat mengharapkan bahwa nilai-nilai budaya yang baru akan diterima dengan cepat.

Budaya oraganisasi ditetapkan dengan orientasi-orientasi bersama, yang menyatukan berbagai bidang keahlian dan kedudukan personil organisasi dalam suatu sistem nilai pada tingkat kedalaman yang berbeda dan memberi identitas yang berbeda. Organisasi mempunyai kepribadian sebagai suatu sistem yang diterima secara bersama, yang seharusnya menghasilkan organisasi dan mutu yang kuat. Mempunyai budaya organisasi yang efektif mempunyai budaya mutu yang kuat dan berbeda yaitu kompetitif.

\section{MENINGKATKAN KINERJA MELALUI KOMITMEN DAN BUDAYA ORGANISASI}

Dalam organisasi apapun, terlebih lagi dalam dunia bisnis, komitmen seseorang terhadap profesinya maupun organisasi tempat bekerja seringkali menjadi syarat yang paling utama. Diberbagai perusahaan, komitmen sebagai salah satu persyaratan untuk menduduki posisi yang ditawarkan, hal ini menunjukkan pentingnya komitmen didalam dunia kerja. Bentuk dari komitmen seseorang dalam dunia kerja diperusahaan bentuknya bagaimana hubungan antara karyawan dengan pekerjaan ditempat karyawan tersebut bekerja.

Cara perusahaan dalam memperlakukan karyawannya dengan baik akan menciptakan komitmen yang baik dari karyawannya. Kondisi seperti ini dapat meningkatkan kinerja karyawan dalam rangka mencapai tujuan perusahaan. Komitmen organisasi memiliki hubungan yang penting dengan kinerja, komitmen yang meningkat menyebabkan efektivitas dan efesien kerja meningkat pula.

Kinerja yang baik akan sangat sulit diperoleh jika karyawan tidak memiliki komitmen terhadap perusahaan, komitmen merupakan alasan karyawan untuk tetap tinggal dan bekerja diperusahaan. Bentuk komitmen karyawan bisa diwujudkan antara lain dalam beberapa hal sebagai berikut:

1. Karyawan senantiasa komitmen untuk mencapai tujuan organisasi.

2. Karyawan senantiasa komitmen dalam melaksanakan tugas pokok dan fungsinya

3. Karyawan senantiasa komitmen untuk meningkatkan mutu sumber daya manusia bersangkutan dan mutu produk.

4. Karyawan senantiasa komitmen untuk berdedikasi pada organisasi secara kritis dan rasional.

Pada dasarnya melaksanakan komitmen sama saja maknanya dengan menjalankan kewajiban, tanggung jawab, dan janji yang membatasi kebebasan seseorang untuk 
melakukan sesuatu. Di sisi lain komitmen berarti adanya ketaatasasan seseorang dalam bertindak sejalan dengan janji-janjinya. Semakin tinggi derajad komitmen karyawan semakin tinggi pula kinerja yang dicapainya dan semakin efetif suatu perusahaan dalam mencapai tujuannya. Ada komitmen yang sangat tinggi dan ada yang sangat rendah.

Berdasarkan penjelasan di atas, dapat dikatakan bahwa komitmen organisasi dapat meningkatkan kinerja karyawan karena dengan memilki komitmen yang tinggi maka seorang karyawan akan melaksanakan tugas atau pekerjaannya dengan tertib dan lancar sehingga hasil kerjanya akan meningkat serta akan berdampak pula pada tujuan perusahaan yang dapat dicapai secara optimal.

Disamping faktor komitmen, budaya organisasi juga sangat berpengaruh terhadap kinerja perusahaan. Semua organisasi mempunyai satu budaya dimana budaya tersebut mempunyai pengaruh yang bermakna pada sikap dan perilaku anggota-anggota organisasi (Robbins, 1996). Budaya organisasi berkaitan erat dengan persepsi terhadap nilai-nilai dan lingkungannya, lalu persepsi itu melahirkan makna dan pandangan hidup yang akan mempengaruhi sikap dan tingkah laku karyawan dan manajemen dalam bekerja. Setiap karyawan dan manajemen seharusnya memiliki sudut pandang atau pemahaman yang sama tentang makna budaya organisasi sehingga efektivitas kerja dalam rangka mencapai tujuan organisasi dapat tercapai. Budaya dalam organisasi diaktualisasikan sangat beragam. Bisa dalam bentuk dedikasi/loyalitas, tanggung jawab, kerjasama, kedisiplinan, kejujuran, ketekunan, semangat, mutu kerja, keadilan, dan integritas kepribadian.

\section{KESIMPULAN}

Komitmen organisasi terhadap efektivitas kerja memiliki implikasi bahwa suatu kekuatan relatif setiap pegawai memiliki kecepatan dan ketepatan dalam penyelesaian tugas-tugas. Tidak semua pegawai dapat menyesuaikan diri terhadap perkembangan organisasi maka setiap perubahan organisasi selalu menghadapi berbagai masalah, terutama adalah penolakan atas perubahan (resistance to change). Penolakan atas perubahan tidak selalu muncul dalam bentuk standar (eksplisit) dan segera misalnya mengajukan protes, mengancam mogok, demontrasi dan sejenisnya tetapi juga ada penolakan secara eksplisit dan lambat laun seperti loyalitas pada organisasi menurun, motivasi berkurang, kesaahan kerja meningkat, kedisipilnan berkurang dan lain-lain. Kultur atau kebiasaan memiliki implikasi terhadap kecepatan dan ketepatan dalam penyelesaian pekerjaan. Budaya organisasi yang sehat berpengaruh terhadap peningkatan kinerja.

\section{SARAN}

Adapun saran untuk diagendakan penelitian kuantitatif dimasa yang akan datang yaitu dapat mengambil sampel dari berbagai perusahaan. Hal ini dimaksudkan untuk menguji konsistensi hasil penelitian antara penelitian kualitatatif ini dengan penelitian yang berbeda. Misalnya bagi peneliti berikutnya dapat mengambil objek penelitian tidak hanya sebatas pada perusahaan melainkan dapat menguji pada berbagai organisasi yang ada. 


\section{DAFTAR PUSTAKA}

Arikunto,S.2003. Prosedur penelitian,suatu pendekatan praktis. Jakarta: Rineka Cipta.

Arikunto,S.2005. Prosedur penelitian,suatu pendekatan praktis. Jakarta: Rineka Cipta.

Cochran,William, G.1991. Teknik Penarikan Sampel. Terjemahan. Rudiansyah, Jakarta: Ul press.

Colquitt Jasson A, Jeffery A, Lepine, Michael J .Wasson 2009. Organizational Behavior. New York: Mc Graw Hill.

Gibson, James, Jhon M., Ivancevich, and Hames H Donelly. Jr.1996 Organisasi: Perilaku, Struktur,dan proses. Terjemahkan Agus Darma. Jakarta: Erlangga.

Gibson, Ivancevich, Donelly. 1997. Organisasi, Prilaku, Struktur proses.

Terjemahkan Agus Dharma. Jakarta: Erlangga.

Hamzah, B. Uno.2007. Teori Motivasi dan Pengukurannya. Jakarta: Bumi Aksara.

Hasan, Bahtiar.2007. Hubungan Antara Komitmen Terhadap tugas dan iklim organisasi Dengan Disiplin Kerja Guru Madrasah Aliyah Kabupaten Aceh Timur. Tesis. Program Pascasarjana Universitas Negeri Medan.

Hasibuan,H. Malayu S.P. 2008.Manajemen Sumber Daya Manusia .Edisi Revisi,Cetakan 10: Jakarta: Bumi Aksara.

Ivancevich, Jhon M, Robert K, and Michael T.M. 2006. Perilaku dan Manajemen Organisasi. Alih Bahasa: Gina Gania. Jakarta: Erlangga.

Kusnendi. 2005. Analisis Jalur Konsep dan Aplikasi dengan Program SPSS \& Lisrel 8. Bandung: UPI.

Lumban Gaol, Masdiana,2010." Pengaruh Persepsi Guru tentang kepemimpinan kepala sekolah ,Motivasi Kerja, dan Pengendalian Stres Terhadap

Komitmen Guru" Tesis.PPs Unimed.

Luthans, Fred 1998. Organization Behavior. Third Edition. London: MeGraw Hill International Book Company.

Mangkunegara, Prabu Anwar. 2009. Evaluasi Kinerja SDM. Bandung: Refika Aditama.

Manullang, Belferik, 2006. Kepemimpinan Pedagogis, membangun karakter sumber daya manusia. Medan :Program Pascasarjana UNIMED.

Manurung, Sari, 2011. "Pengaruh Iklim organisasi, Empati, dan kebutuhan Berprestasi terhadap Komitmen Afektif Guru" Tesis. PPs Unimed.

Minner, Jhon B, 1992. Industrial Organizational Psychology. New York: Random Grawhill,Inc.

Mathis, Robert L dan Jhon H.Jackson .2006. Human Resource Management: Manajemen Sumber daya Manusia , Buku I,Alih Bahasa: Diana Angelia. Jakarta :Salemba Empat.

Mulyana, D dan Rakhmat J.2003.Komunikasi Antar Budaya:Panduan Berkomunikasi Dengan Orang-Orang Berbeda Budaya,Bandung: 


\section{Rosdakarya.}

Mutmainnah, Sri.2008. “ Memberdayakan Potensi Guru Melalui standar

Kompetensi dan Sertifikasi Pendidik” Jurnal. Kajian Manajemen Pendidikan.

Jakarta: UHAMKA.

Newstrom Jhon W. And Davis,Keiths.1989. Perilaku Dalam Organisasi.Edisi Ketujuh. Alih Bahasa:Agus Dharma.Jakarta:Erlangga.

Purba Sukarman.2010. Kinerja Pimpinan Jurusan Di Perguruan Tinggi.Yogyakarta :LaksBang Pressindo.

Purwanto,N.1998. Administrasi dan Supervisi Pendidikan, Bandung: Remaja Rosdakarya.

Robbins, Stephen, 1996. Perilaku Organisasi .Terjemahan Benjamin M. Jakarta: Indeks. ..2006. Perilaku Organisasi. Alih Bahasa Hadiana Pudja Atmaka, Jakarta: Prehalindo.

.2007. Manajemen.Edisi kedelapan.Alih Bahasa Harry Selamet dan Ernawati Lestari,indonesia:Macan Jaya Lestari.

Sagala, H. Syaiful.2008. Budaya dan Reinventing, Organisasi pendidikan. Bandung Alfabeta.

Sahertian, Piet A 2000. Konsep Dasar \& Teknik Supervisi Pendidikan Dalam Rangka

Pengembangan Sumber Daya Manusia Cetakan 1. Jakarta: Rineka Cipta.

Sopiah,2008. Perilaku Organisasi. Yogyakarta: Andi.

Sugiono,2009.metode.penelitian Pendidikan.Bandung:Alfabeta.

Sutrisno,Edi.2009. Manajemen Sumber Daya Manusia. Jakarta: Kencana. 2010. Budaya Organisasi.Jakarta: Kencana Sudjana.1989.Metode

Statistik .Tarsito :bandung.

Undang-undang Sisdiknas No. 20 tahun 2003,tentang sistem pendidikan

Nasional,jakarta.

Undang-undang Sisdiknas No. 14 tahun 2005, tentang guru dan dosen,jakarta.

Usman,H.2008.Manajemen:teori,praktik,dan riset pendidikan.jakarta:Bumi Aksara.

Winardi, J. 2007. Motivasi dan Pemotivasian Dalam Manajemen. Jakarta: Grafindo Persada.

Wirawan,2008. Budaya dan Iklim Organisasi. Jakarta: Salemba Empat.

Yulk Gary.2007. Kepemimpinan dalam Organisasi.Alih bahasa: Budi Suprianto Indeks: Jakarta. 